mescaline. The tissue concentrations of the methyl donor substance $s$-adenosylmethionine are described by Baldessarini, and the final chapter reports the elegant studies of Mudd et al. in homocystinuria.

Many of the data were obviously assembled in support of one or other of the various hypotheses, but no con. clusive comments are possible at this time. In an inspired summary Kety does attempt a critical synthesis through which a common thread of disordered methylation is drawn.

Alan A. Boulton

\section{PROTEINS FOR PROTECTION}

Immunological Properties of Protein Hormones Edited by Filippo Polvani and P. Crosignani. (Proceedings of a Meeting organized under the auspices of Academia Nazionale dei Lincei and of Consiglio Nazionale delle Ricercho, Rome, June 1964.) (International Endocrinological Symposia.) Pp. xii +259 . (New York : Academic Press, Inc.; London: Academic Press, Inc. (London), Ltd., 1966.) n.p.

Tне proceedings of a symposium on the immunological properties of protein hormones held in Rome three years ago have now been published. 'The impetus for tho marked progress which has been made in this field in recent years was provided by the need for reliable and practicable methods for the detection and measurement of protein hormones in human body fluids.

The book begins with an introduction to the use of fluorescent antibody techniques for the localization of hormones, an exciting aspect because, with these methods, it may eventually be possible to identify the site of synthosis, storage and action of a hormone. 'The emphasis of the contributions, however, was focused on the morits of quantitative tests for the estimation of gonadotrophins, growth hormone and insulin. Information about the concentrations of these hormonos in physiological and pathological statos is required for a real understanding of their rolo in regulatory mechanisms, and this is emphasized by the results of some of the experiments which indicate that the sceretion of growth hormone is greatly influenced by various factors such as the administration of glucose and of insulin. Similar immunological procedures are described in some detail, and this inevitably results in a cortain amount of duplication in the texts of the different papers.

The principal fact which emerges is that the antigenic determinant sites of a protein hormone are not necessarily those which are responsible for its specific biological activity. In fact the results of comparativo assays, particularly in the case of the gonadotrophins, indicate that there is not always a good correlation between the rosults of biological and immunological assays: a finding which suggests that some caution is required before replacing biological assays by immunological methods.

The most rapid advances in the application of immunological methods to clinical problems are likely to come from the use of radioimmunoassay systems which appear to have greater specificity and increased sensitivity. The essential details of the tochniquo for the radioimmunoassay of growth hormone are described, but the results obtained by different authors are at variance. There is still clearly the problem of interfering factors.

This book contains information which is spread throughout the literature and is reasonably well presented by the editors. It has, unfortunatoly, taken a long timo to appear and tho facts are now very familiar to the active research worker. Tho book would, however, be useful to the worker atternpting for the first time to establish immunological methods for the assay of protein hormones, for it puts into perspective the problems and pitfalls that will be encountered.

\section{ADVERSE REACTIONS}

A Theory of Psychological Reactance

By Jack W. Brehm. (Social Psychology: a Series of Monographs, Treatises, and Texts.) Pp. $x+135$. (New York: Academic Press, Inc.; London: Academic Press, Inc. (London), Ltd., 1966.) $48 s$.

BrenM's thesis is that the individual reacts against attempts to influence him because these are seen as threats to his freedom to decide for himself his own course of action. People experience "psychological reactance", therefore, whenever a behavioural freedom is eliminated or threatened with elimination. A number of predictions are made on the basis of this postulate: subjects should rate a threatened or eliminated behaviour as more attrac. tive than previously, in order, presumably, to reassert their freedom; if customers are given verbal and monetary inducemonts to buy a particular product, the greater the inducements the more psychological reactance will be created with consequently less compliance; the more clearly people are aware that someone is attempting to change their attitudes, the more they will resist such a change. This monograph reports a series of oxperiments which, in gonoral, support these and other predictions.

The idea that the individual values the freedom to make his own decisions is no new theory, as Brehm appears to think. Others, notably Riesman and Flügel, have used the term "autonomy" to denote this concept. The merit of Brehm's work lies in the demonstration that the frustration of autonomy can be studied experimentally. The theory must, however, be made a great deal more precise if experimentation is to prove fruitful. For example, if a person is told that a certain course of action is no longer open to him, he may lower his estimation of this action-a "sour grapes effect", as Brehm calls it. But the theory does not specify the conditions in which this or the opposite effect will obtain. Future work should be directed at clarifying such ambiguitios.

Neil Bolton

\section{HUMAN GROUPS}

\section{Caste and Race}

Comparative Approaches. Edited by Anthony de Reuck and Julio Knight. Pp. xi +348 . (A Ciba Foundation Volume.) (London: J. and A. Churchill, Ltd., 1967.) $60 s$.

THIs book presents the papers given and summarizes the ensuing discussions at a Ciba Foundation Symposium on Caste and Race held in 1966. Without doubt it is of considerable interest to social scientists, including anthropologists, sociologists, social psychologists, students of social chango and the like.

The stage is set by Dr Leach who defines class, caste and slavery, and these definitions are supplomented and amplified by other speakers who also define and consider race and racism. It is evident that certain of the phenomena discussed in this volume have a partly biological basis or "model" as an idcological foundation, as in the case of race relations and racism, while others have a cultural "model" or basis, as with caste. If only because of this marked difference, it is difficult to determine whether it is altogether appropriate to compare the various situations described in this book, including the Indian caste system, tho $\Lambda$ morican raco situation and the Japanese pariah Burakumin. Again it is difficult to establish whether caste is as such, a Hindu phenomenon or whether the appellation has in fact much wider applicability, a problem which is fully dealt with in this volume.

In many of these caste and race conflict situations, precise details of socio-cultural behaviour patterns are of 